умов навчання й проживання, підтримати мотивацію до здобуття освіти 3 метою підготовки конкурентоспроможних фахівців для зарубіжних країн.

\title{
Література:
}

1. Катс Дж. Поколения и стили обучения / Джон Катс. - М. : МАПДО ; Новочеркасск : НОК, 2011. - 121 с.

2. Колосова Г. Хто такі «ікси» та «ігреки» і як їм порозумітися 3 «зетами» [Електронний ресурс] / Ганна Колосова. - Режим доступу : https://www.pedrada.com.ua/article/1236-qqq-17-m3-15-03-2017-hto-takksi-ta-greki-yak-m-porozumtisya-z-zetami.

3. Покоління Z: как правильно ставить задачи сегодняшним двадцатилетним [Электронный ресурс]. - Режим доступа : https://vc.ru/flood/10701-generation-z.

4. Straus, William, Hove, Neil (1991) Generations: the history of America's future. 1584 to 2069. New York: Perennial, - 544 p.

DOI https://doi.org/10.30525/978-9934-26-146-6-5

\section{ПСИХОЛОГІЧНІ ОСОБЛИВОСТІ РОЗВИТКУ УВАГИ У ДІТЕЙ МОЛОДШОГО ШКІЛЬНОГО ВІКУ}

\author{
Бушусва Т. В.
}

кандидат психологічних наук, дочент, професор кафедри загальної і сочіальної психологї̈ та психотерапї Національний педагогічний університет імені М. П. Драгоманова

\section{Авер'янова А. М.}

аспірант кафедри загальної і сочіальної психології та психотерапії Національний педагогічний університет імені М. П. Драгоманова м. Київ, Украӥна

Зростаючий темп життя, високий динамізм діяльності, розвиток інформаційних технологій пред'являють особливі вимоги до уваги людини, яка визначає особливості функціонування пізнавальних процесів та поведінки. Виділення і зосередженість на важливому, відсторонення від другорядного допомагає орієнтуватися в широкому інформаційному просторі. При цьому властивості уваги пов'язані із певною індивідуальною стратегією пізнання - когнітивним стилем. Врахування особливостей когнітивного стилю та їх зв'язку 3 
властивостями уваги учнів сприятиме вдосконаленню ефективності освітньої діяльності. Теоретичний аналіз проблеми дозволив визначити вікову специфіку структури взаємозв'язків параметрів когнітивних стилів та властивостей уваги, зокрема, збільшення кількості зв'язків показників певних когнітивних стилів та властивостей уваги у дорослості порівняно з дошкільним віком [1]. Оскільки сензитивним періодом розвитку уваги, як відомо, визначається молодший шкільний вік, особливого інтересу набуває вивчення зв'язку когнітивного стилю та уваги у молодших школярів.

На першому етапі емпіричного дослідження нами визначалися особливості розвитку властивостей уваги дітей молодшого шкільного віку. Використовувалися методики: методика Мюнстерберга (визначення концентрації уваги), методика «Запам'ятай та розстав крапки» (визначення обсягу уваги), методика «Кільця Ландольта» (визначення стійкості, розподілу, перемикання уваги). Дослідження проводилося на базі загальноосвітньої школи № 286 та навчальновиховного комплексу «Міжнародний ліцей МАУП» міста Києва. Вибірка дослідження: 239 учнів молодшого шкільного віку (учнів 1 класу - 64 особи, учнів 2 класу - 58 осіб, учнів 3 класу - 61 особа, учнів 4 класу - 56 осіб).

Узагальнені результати визначення рівня розвитку властивостей уваги у досліджуваної вибірки молодших школярів засвідчують наступне. Рівень розвитку концентрації уваги 46,4 \% досліджуваних $є$ дуже високим; 11,7\% - високим; 17,0\% - низьким; 12,6\% - дуже низьким. Рівень розвитку обсягу уваги 27,6\% досліджуваних є дуже високим; 17,2\% - високим; разом 3 тим, 16,0\% досліджуваних мають низький рівень розвитку обсягу уваги, а $25,9 \%$ - дуже низький. Більшість молодших школярів $(66,1 \%)$ мають середній рівень розвитку стійкості уваги, а 19,0\% - низький. Також більшість досліджуваних (56,9\%) мають середній рівень розвитку перемикання уваги, а 29,0\% низький. Рівень розвитку розподілу уваги у 61,0\% учнів - низький, у $31,0 \%$ - дуже низький.

Вивчалася динаміка розвитку властивостей уваги у молодших школярів 3 першого по четвертий клас навчання. В учнів першого класу за середніми значеннями показників визначається низький рівень розвитку концентрації ( $\mathrm{M} \pm \sigma=3,42 \pm 2,23)$, обсягу $(\mathrm{M} \pm \sigma=2,53 \pm 0,76)$, розподілу $(\mathrm{M} \pm \sigma=0,22 \pm 0,11)$, перемикання $(\mathrm{M} \pm \sigma=0,39 \pm 0,16)$ уваги та середній рівень розвитку стійкості уваги ( $\mathrm{M} \pm \sigma=0,48 \pm 0,17)$. У учнів другого класу до високого рівня розвитку зростають показники концентрації $(\mathrm{M} \pm \sigma=8,10 \pm 4,22)$ та стійкості $(\mathrm{M} \pm \sigma=0,63 \pm 0,19)$ уваги; до середнього рівня розвитку - показники обсягу $(\mathrm{M} \pm \sigma=4,34 \pm 1,85)$ та 
перемикання уваги ( $\mathrm{M} \pm \sigma=0,57 \pm 0,15)$; розподіл уваги залишається на низькому рівні розвитку $(\mathrm{M} \pm \sigma=0,29 \pm 0,10)$. Відмінності у рівні розвитку властивостей уваги першокласників та другокласників $\epsilon$ статистично значущими ( $<0,001)$. В учнів третього класу концентрація уваги досягає дуже високого рівня розвитку $(\mathrm{M} \pm \sigma=10,15 \pm 4,68)$; обсяг $(\mathrm{M} \pm \sigma=4,79 \pm 2,27)$, стійкість ( $\mathrm{M} \pm \sigma=0,76 \pm 0,20)$ та перемикання $(\mathrm{M} \pm \sigma=0,67 \pm 0,21)$ уваги - високого рівня розвитку; розподіл уваги залишається на низькому рівні розвитку ( $\mathrm{M} \pm \sigma=0,31 \pm 0,11)$. Статистично значущі відмінності виявлено в розвитку концентрації $(\mathrm{p}=0,01)$, стійкості $(\mathrm{p}<0,001)$ та перемикання $(\mathrm{p}<0,01)$ уваги учнів другого та третього класів. Статистично значущих відмінностей між показниками обсягу та розподілу уваги цих учнів не виявлено (p>0,05). В учнів четвертого класу визначений дуже високий рівень розвитку концентрації ( $\mathrm{M} \pm \sigma=12,95 \pm 4,38)$, обсягу ( $\mathrm{M} \pm \sigma=5,79 \pm 1,47)$, стійкості $(\mathrm{M} \pm \sigma=0,90 \pm 0,21)$ та перемикання $(\mathrm{M} \pm \sigma=0,84 \pm 0,30)$ уваги. Розподіл уваги четвертокласників досягає середнього рівня розвитку $(\mathrm{M} \pm \sigma=0,41$ $\pm 0,11)$. Виявлені статистично значущі відмінності в показниках концентрації ( $\mathrm{p}=0,001)$, обсягу $(\mathrm{p}<0,01)$, стійкості ( $<<0,001)$, розподілу $(\mathrm{p}<0,001)$ та перемикання $(\mathrm{p}<0,001)$ уваги у молодших школярів третього та четвертого класів.

Отже, динаміка розвитку властивостей уваги у дітей молодшого шкільного віку має нерівномірний характер: найбільш інтенсивний розвиток властивостей уваги спостерігається на початковому етапі (перший-другий класи), менш інтенсивний на завершальному етапі (третій-четвертий класи) і найменш інтенсивний на етапі другий-третій класи.

Також розвиток різних властивостей уваги молодших школярів відбувається з різною інтенсивністю. Згідно отриманим результатам, найбільш інтенсивного розвитку зазнає концентрація уваги (середні показники концентрації уваги у четвертокласників у 3,8 разів вищі, ніж у першокласників). Менш інтенсивні зміни виявлено у показниках обсягу (середні показники обсягу уваги учнів четвертого класу у 2,3 рази вищі, ніж у учнів першого класу) та перемикання (середні показники перемикання уваги четвертокласників вищі у 2,2 рази, ніж у першокласників). Найменш інтенсивних змін зазнають стійкість та розподіл уваги: середні їх показники в учнів четвертого класу у 1,9 рази більші, ніж у першокласників. Серед показників, які характеризують особливості динаміки стійкості та розподілу уваги молодших школярів, розглядались швидкість переробки інформації та точність роботи, які визначаються за методикою «Кільця Ландольта». Виявлене поступове зростання показників швидкості при оцінці стійкості уваги учнів на всіх 
етапах навчання $(p \leq 0,001)$. Усереднені показники точності роботи в оцінці стійкості уваги учнів на різних етапах навчання статистично значущо не розрізняються $(\mathrm{p}>0,05)$. Показники швидкості при оцінці розподілу уваги учнів молодшого шкільного віку зростають на етапі перший-другий класи $(p=0,01)$, значущо не змінюються на етапі другий-третій класи $(\mathrm{p}>0,05) \mathrm{i}$ знову зростають на етапі третій-четвертий класи $(p<0,001)$. Усереднені показники точності роботи в оцінці розподілу уваги учнів на різних етапах навчання статистично значущо не розрізняються ( $>>0,05)$. Отже, зростання показників стійкості та розподілу уваги молодших школярів відбувається за рахунок росту швидкості переробки інформації при сталих показниках точності роботи.

Дослідження динаміки зв'язку між властивостями уваги на різних етапах навчання молодших школярів здійснювалось за допомогою кореляційного аналізу. Виявлено, що провідною в структурі властивостей уваги першокласників є стійкість уваги, яка має значущі зв'язки з усіма іншими властивостями. В структурі властивостей уваги учнів другого класу провідними $\epsilon$ розподіл та стійкість уваги. Кореляційна матриця показників властивостей уваги учнів третього класу містить лише значущі зв'язки між стійкістю, розподілом та перемиканням уваги, а концентрація і обсяг уваги не мають значущих зв'язків 3 іншими властивостями уваги. Тож, в кореляційній матриці показників властивостей уваги третьокласників не можна визначити ознаку-індикатор, яка викликає «стягування» інших властивостей у плеяду. Провідною властивістю в структурі властивостей уваги учнів четвертого класу $є$ розподіл уваги, що має значущі зв'язки з усіма іншими властивостями. Крім зміни ознаки-індикатора, в кореляційній матриці показників властивостей уваги четвертокласників, порівняно 3 першокласниками, фіксується ще одна відмінність: обсяг уваги першокласників має значущий зв'язок зі стійкістю $(r=0,263, \mathrm{p}<0,05)$ та перемиканням уваги $(\mathrm{r}=0,261, \mathrm{p}<0,05)$, а у четвертокласників обсяг уваги має значущий зв'язок тільки з розподілом уваги (r=0,403, p<0,01).

Дослідження статевих відмінностей в розвитку властивостей уваги дітей молодшого шкільного виявило вищий рівень розвитку концентрації $(\mathrm{M} \pm \sigma=9,26 \pm 5,76)$ та перемикання $(\mathrm{M} \pm \sigma=0,65 \pm 0,30)$ уваги у дівчат, порівняно із розвитком концентрації $(\mathrm{M} \pm \sigma=7,84 \pm 4,76)$ та перемикання $(\mathrm{M} \pm \sigma=0,57 \pm 0,23)$ уваги у хлопчиків $(\mathrm{p}<0,05)$. При цьому індивідуальна варіативність показників концентрації та перемикання уваги дівчат більша, ніж у хлопців. Значущих статевих відмінностей за показниками обсягу, стійкості, розподілу уваги у дітей молодшого шкільного віку не виявлено. 
Результати дослідження свідчать, що у молодшому шкільному віці діапазон індивідуальних відмінностей в розвитку концентрації, обсягу та перемикання уваги розширюється. Найменша варіативність властива показникам розподілу уваги учнів і вона $є$ сталою на різних етапах навчання молодших школярів.

Отже, розвиток властивостей уваги молодших школярів має нерівномірний характер (нерівномірність розвитку на різних етапах навчання та нерівномірність інтенсивності розвитку різних властивостей уваги); провідними в структурі властивостей уваги $\epsilon$ стійкість та розподіл уваги, які зазнають найменш інтенсивних змін впродовж молодшого шкільного віку.

\title{
Література:
}

1. Бушуєва Т.В., Авер'янова А.М. Когнітивний стиль та властивості уваги особистості. Науковий часопис НПУ імені М.П. Драгоманова. Серія 12. Психологічні науки, 2020. Вип. 11 (56). С. 36-46.

DOI https://doi.org/10.30525/978-9934-26-146-6-6

\section{ПРОТИРІЧЧЯ ПСИХОЛОГО-ПЕДАГОГІЧНОГО СПІЛКУВАННЯ В ІНФОРМАЦИЙНО-ТЕХНОЛОГІЧНИХ МЕТОДАХ СУЧАСНОЇ ОСВІТИ}

\author{
Зайченко Л. С. \\ старший викладач кафедри гуманітарно-фундаментальних дисииплін \\ Сєвєродонеиький інститут \\ ПрАТ «ВНЗ «Міжрегіональна Академія управління персоналом» \\ м. Сєвєродонецьк, Луганська область, Украӥна
}

Основним результатом навчання у вищий школі повинен стати сформований індивідуальний стиль трудової діяльності. Мова йде не тільки про майбутнього психолога, а й про будь - якого іншого спеціаліста.

Але задовго до трудової діяльності, [4, с. 24], студент повинен опанувати змістом великої кількості навчальних дисциплін , що закладені в освітніх стандартах. Освітній стандарт визначає їх конкретний склад і об'єм годин, виділених на кожну з них для лекцій, семінарських і практичних занять. Це доволі значний обсяг учбового часу.

Основною ланкою в системі освіти виступае зміст освіти. 